Loyalitas Kreativitas

Aldi Masyarakat Kreatif
Program Studi Ekonomi Manajemen Universitas Pamulang

Jurnal LOKABMAS Kreatif Vol.02,No.02.Juli 2021 Hal.51-57

Email:jurnalkreatif.manajemen@gmail.com

\title{
PENYULUHAN DAN PEMAHAMAN PEMASARANPRODUK YANG KREATIF DAN INOVATIF PADA UMKM MERTA YASA, BAMBU MAS, DESA BELEGA, KABUPATEN GIANYAR, DENPASAR, BALI
}

\author{
Lismiatun, Juwita Ramadani Fitria, Bambang Purnomo Yanuarso, \\ Hira Maulida, Selvy Dwi Widiyanti
}

Dosen Ekonomi Fakultas Ekonomi Universitas Pamulang

Email : dosen01460@unpam.ac.id,dosen00976@unpam.ac.id dosen02142@unpam.ac.id, dosen02450@unpam.ac.id,dosen02458@unpam.ac.id

\begin{abstract}
ABSTRAK
Tujuan dari Kegiatan Pengabdian Kepada Masyarakat adalah untuk melaksanakan salah satu TriDharma Perguruan Tinggi. Selain itu agar para penggerak bisnis UMKM dapat meningkatkan pemasaran dan membantu semua Program Pemerintah untuk masyarakat sekitar terutama dalam memberdayakan keaktifan anggotanya berwirausaha mengembangkan potensi wilayah terutama di lingkungan masyarakat Desa Belega, guna meningkatkan kesadaran untuk mendapatkan kesejahteraan yang lebih baik lagi. Metode kegiatan yang digunakan adalah kami melakukan survey dengan mendatangi lokasi serta melakukan wawancara dan observasi kepada pemilik UMKM UD Merta Yasa, Desa Belega, Kabupaten Gianyar, Denpasar, Bali dan menyampaikan maksud akan memberikan pelatihan pada tanggal 1-3 Maret. Pelatihan ini bertujuan agar para anggota dan pemilik UMKM Merta Yasa dalam pengembangan usaha UMKM atau Usaha Rumahan ini mampu berkembang yang tentunya harus didasari dengan memiliki pengetahuan manajemen yang baik. Hasil pengabdian masyarakat yang diperoleh adalah bertambahnya keilmuan dan pengalaman para anggota dan pemilik UMKM Merta Yasa yang selama ini masih minim tentang pemasaran, promosi, manajemen keuangan, suply chain, inventory dan pemanfaatan teknologi digital sehingga mereka memiliki pandangan yang lebih baik lagi tentang pentingnya meningkatkan keilmuan mereka sebagai wirausahawan atau enterepreneur sehingga mampu menciptakan produk unggulan yang berkualitas agar mampu menembus pasar global. diharapkan mampu memberikan semangat baru bagi kita dalam menyampaikan materi dan motivasi serta berkontribusi bagi generasi muda, baik dilingkungan sekolah, kampus, masyarakat dan keluarga. Pelatihan tersebut juga diharapkan tidak hanya berpedoman pada hasil saja melainkan juga pada proses sehingga masyarakat mampu mempertahankan dan juga meningkatkan kualitas dari produk jualannya.
\end{abstract}

Keywords: entrepreneur, pemasaran, teknologi

\begin{abstract}
ABSTRAC
The purpose of Community Service Activities is to carry out one of the TriDharma of Higher Education. In addition, UMKM business activists can increase marketing and assist all Government Programs for the surrounding community, especially in empowering the active members of their members in entrepreneurship to develop regional potential, especially in the Belega Village community, in order to increase awareness to get better welfare. The activity method used was that we conducted a survey by visiting the location and conducting interviews and observations to the owner of UMKM UD Merta Yasa, Belega Village, Gianyar Regency,
\end{abstract}


Loyalitas Kreativitas Aldi Masyarakat Kreatif
P-ISSN 2722-2101, E-ISSN 2722-4201

Program Studi Ekonomi Manajemen Universitas Pamulang Jurnal LOKABMAS Kreatif Vol.02,No.02.Juli 2021 Hal.51-57 Email:jurnalkreatif.manajemen@gmail.com

Denpasar, Bali and conveyed the intention to provide training on March 1-3. This training aims to enable the members and owners of UMKM Merta Yasa to develop their UMKM or Home Business businesses, which of course must be based on good management knowledge. The results of community service obtained are increased knowledge and experience of the members and owners of UMKM Merta Yasa who have so far been minimal regarding marketing, promotion, financial management, supply chain, inventory and the use of digital technology so that they have a better view of the importance of improving knowledge they are entrepreneurs or entrepreneurs so as to be able to create superior quality products to be able to penetrate the global market. It is hoped that it will be able to provide new enthusiasm for us in conveying material and motivation as well as contributing to the younger generation, both in the school, campus, community and family environment. It is also hoped that the training will not only be guided by the results but also on the process so that the community is able to maintain and also improve the quality of their selling products.

\section{Keywords: entrepreneur, marketing, technology}

\section{PENDAHULUAN}

Marketing adalah ujung tombak dari keberhasilan suatu perusahaan, karena setiap perusahaan pastinya menawarkan produk atau layanan jasa, bukan ? Jika marketing di perusahaan berfungsi dengan sangat baik, maka perusahaan tersebut dapat meraih puncak kesuksesannya. Tujuan pemasaran atau marketing bukan hanya mencari profit, namun juga fokus pada apa yang diperlukan oleh para konsumen, sehingga produk atau jasa yang diawarkan benar-benar bermanfaat bagi kelangsungan hidup mereka.

Transformasi pada masa era globalisasi dan digitaliasi sekarangi ini, terutama dalam bidang ilmu pengetahuan dan teknologi (IPTEK) serta sistem informasi berperan sangat penting. Jenis-jenis pemasaran di era modern ini memang sangat beragam. Contoh pemasaran yang kekinian adalah dengan mempromosikan produk atau layanan jasa melalui media sosial yang banyak sekali digandrungi oleh para pengikut platform sosial ini. Dikarenakan persaingan di dalam dunia bisnis semakin ketat, maka setiap bidang pemasaran pada perusahaan harus "memutar otak" mereka dengan memikirkan konsep pemasaran dan strategi pemasaran yang cerdas, efektif dan tepat.

Banyaknya kemudahan dan fungsi dari penggunaan media digital, mendorong masyarakat atau pengusaha untuk memaanfaatkan media digital tersebut pada setiap kegiatannya. Fungsi lain dari penggunaan media digital meliputi : branding, sharing, promosi, maupun marketing. Perkembangan teknologi informasi dan internet juga berpengaruh besar terhadap perkembangan di bidang promosi produk. Hal tersebut tentunya sangat menguntungkan bagi dunia promosi produk karena kemudian terjadi peningkatan efektivitas jika dibandingkan dengan media kovensional.

Contoh strategi pemasaran konvensional yang diterapkan dari dulu hingga sekarang misalnya iklan, direct marketing, dan sales promotion. Ketiga contoh tersebut bukan berarti tidak bermanfaat lagi di masa sekarang, namun perusahaan tentunya perlu mempertimbangkan media baru dan strategi baru agar pemasaran menjadi lebih efektif dan efisien. Masalah yang sampai saat ini masih perlu diperhatikan adalah kurangnya kesadaran masyarakat atau pengusaha untuk memanfaatkan media digital sebagai sarana untuk mengembangkan kegiatannya, khususnya di Wilayah Desa Blega Kabupaten Gianyar, Denpasar, Bali.

Aspek utama yang mempengaruhi peningkatan efektivitas promosi produk melalui internet adalah media yang interaktif, bersifat fleksibel dengan pengertian adanya pertukaran pesan dua arah dan media yang responsif.

Kesadaran tentang perkembangan teknologi khususnya bagi para pengusaha yang ada di daerah pelosok desa dalam memaksimalkan pemanfaatan teknologi belum produktif di era digital sekarang ini 
Dalam usaha mengembangkan UMKM, pemerintah memungkinkan kegiatan usaha UMKM menjadi jaminan untuk mengakses kredit pembiayaan usaha. Saat ini, proses pendaftaran Hak Kekayaan Intelektual lebih mudah dan sederhana. Begitu pula untuk impor bahan baku dan bahan penolong industri dipermudah sekaligus fasilitas ekspor bagi UMKM. Pemerintah juga mengalokasikan produkUMK dan koperasi dari hasil produksi dalam negeri dalam pengadaan barang/jasa pemerintah.

Berdasarkan pemaparan pengertian UMKM, fungsi, peran dan jenisnya, maka dapat disimpulkan bahwa UMKM adalah penggerak utama roda perekonomian Indonesia. Tentunya hal ini juga harus diiringi dengan regulasi-regulasi pemerintah yang memudahkan para pelaku bisnis UMKM agar dapat berkembang pesat. Karenanya setiap desa / kelurahan atau komunitas adat sederajat dapat menumbuhkan dan mengembangkan UMKnya sendiri. Gerakannya di bidang Ekonomi, berarti bahwa semua upaya program dan kegiatan yang diselenggarakan UMKM ditujukan guna mewujudkan kesejahteraan sosial masyarakat terutama generasi mudanya.

\section{RUMUSAN MASALAH}

Dengan mempertimbangkan latar belakang yang telah dijelaskan diatas kami berinisiatif untuk membentuk pengabdian masyarakat kepada anggotaa dan pemilik UMKM Merta Yasa, Desa Belega, Kabupaten Gianyar, Denpasar, Bali khususnya dalam program pelatihan agar dapat menciptakan peluang produk baru yang inovatif kerajinan bambu sehingga dapat menembus pasa global.

Berdasarkan uraian analisis situasi permsalahan, maka dapat diperoleh rumusan masalah yang dihadapi mitra adalah :

1. Bagaimana memberikan pemahaman cara memasarkan produk?

2. Bagaimana contoh produk yang kreatif ?

3. Bagaimana cara membuat produk yang kreatif dan Inovatif?

\section{TUJUAN PELAKSANAAN}

1. Memberikan pengetahuan kepada anggota dan pemilik UMKM Merta Yasa, Desa Belega, Kabupaten Gianyar, Bali dalam memasarkan produk UMKM lebih efektif dan efisien menggunakan teknologi digital.

2. Memberikan Memberikan ide ide tentang bagaimana contoh dan cara pembuatan produk yang kreatif kepada para anggota UMKM Merta Yasa, Desa Belega, Kabupaten Gianyar, Bali guna engembangkan potensi diwilayah lingkungan masyarakat.

3. Memberikan gambaran dan pengetahuan kepada para anggota UMKM Merta Yasa, Desa Belega, Kabupaten Gianyar, Bali mengenai cara mengelola keuangan dan manajemen supply chain terhadap produk-produk UMKM.

\section{TINJAUAN PUSTAKA}

\section{Pengertian Pemasaran}

Dalam suatu perusahaan manajemen mempunyai arti penting untuk mencapai tujuan perusahaan, kata "manajemen" sering di artikan sebagai sebuah proses rangkaian kegiatan perencanaan, pengorganisasian, penggerakan, dan pengawasan (controlling) yang dilakukan untuk mencapai tujuan atau target yang telah ditentukan sebelumnya.

Menurut Kotler dan Amstrong (dalam Priansa, 2017:4) menjelaskan manajemen pemasaran ialah suatu upaya manusia untuk mencapai hasil pertukaran yang diinginkan dan membangun hubungan yang erat dengan konsumen dengan cara yang menguntungkan bagi perusahaan.

Pemasaran merupakan salah satu fungsi dari perusahan disamping fungsi lainnya dalam mengelola perusahaan seperti keuangan, produksi dan personalia. Pemasaran adalah keterpaduan beberapa kegiatan antara lain, perencanaan, penentuan produk dan harga, promosi dan distribusi sehingga membentuk suatu kesatuan sistem yang paling berhubungan antara satu dengan lainnya.

Pemasaran umumnya mencakup semua segi kehidupan individu maupun kelompok yang bertujuan untuk memenuhi kebutuhan dan keinginan dengan cara menukarkan produk dan menyalurkan barang produk dan jasa dari produsen ke konsumen. Pemasaran digunakan konsumen untuk memenuhi keutuhan, sedangkan bagi perusahaan membantu suatu organisasi 
Loyalitas Kreativitas Aldi Masyarakat Kreatif menginformasikan produknya kepada masyarakat agar masyarakat mengerti dalam menggunakan produk dari perusahaan tersebut.

Konsep ini masyarakat menegaskan bahwa tugas organisasi dalah menentukan kebutuhan, keinginan dan kepentingan pasar sasaran serta memberikan kepuasaan yang diingkan secara lebih efektif dan efisien. Konsep pemasaran akan lebih terfokuskan pada perusahaan yang memproduksi barang konsumsi daripada barang industri. Konsep pemasaran yang diterapkan ke masyarakat merupakan suatu tugas perusahaan yang berhubungan dengan penentu kebutuhan, keinginan, dan sasaran pasar yang mampu memberikan kepuasan yang lebih efektif dibandingkan dengan pesaing dalam peningkatan dan perlindungan kepentingan konsumen.

\section{Pengertian Produksi}

Dalam kehidupan bermasyarakat guna memenuhi kebutuhan hidup manusia yang 5) beraneka ragam, manusia memerlukan barang dan jasa yang tidak dapat dihasilkan sendiri, suatu kegiatan yang menghasilkan barang dan jasa disebut produksi.

Menurut Sofjan Assauri (2016:153) produksi adalah kegiatan yang melibatkan tenaga manusia, bahan serta peralatan untuk menghasilkan produk yang berguna.

Secara umum proses produksi dapat diartikan sebagai kegiatan atau proses merubah suatu bahan mentah menjadi bahan siap pakai/konsumsi, bentuk, wujud dengan meningkatkan atau menambah manfaat suatu barang atau jasa untuk memenuhi kebutuhan manusia.

Faktor-faktor yang dapat dilakukan untuk mencapai produksi yang optimal antara lain yaitu :

1. Ketersediaan bahan dasar yang akan di produksi

2. Ketersediaan kapasitas alat bantu baik mesin, gunting, atk dll

3. Ketersediaan tenaga kerja atau sumber daya manusia

4. Prediksi besarnya permintaan akan hasil produksi

5. Tersedianya faktor-faktor produksi lainnya yang mendukung.

\section{Pengertian Peluang Usaha}

Peluang usaha adalah sebuah kreasi yang berdiri sendiri, lahir dari pemikiran sendiri, extraordinary, serta kemandirian. Dalam menjalankan usaha pada wirausahawan harus memiliki pemikiran kreatif dan inovatif untuk mendapatkan hasil yang maksimal agar dapat meminimalisir kendala atau hambatan dalam menjalankan usahanya.

\section{A. Sumber Peluang Baru}

1) Cita-cita

Peluang dapat timbul dari cita-cita diri kita sendiri.

2) Riset atau survei pasar

Melakukan tanya jawab dengan konsumen

3) Tekanan

Dengan adanya tekanan terhadap seseorang baik internal ataupun eksternal akan melahirkan banyak ide atau gagasan

4) Minat atau kecenderungan pasar

Mengamati kebutuhan konsumen dipasar dapat menciptakan peluang pasar

Inovasi baru

Adanya kebutuhan akan memunculkan gagasan untuk menciptakan produk baru hadir di masyarakat

6) Pelengkap dari produk yang sudah ada Sebuah produk dapat memberikan peluang usaha dengan membuat produk-produk yang melengkapi

7) Moment atau peristiwa yang digemari

Menurut Robbin dan Coulter peluang usaha adalah merupakan sebuah proses yang melibatkan individu atau kelompok yang menggunakan usaha dan sarana tertentu untuk menciptakan suatu nilai tumbuh guna memenuhi sebuah kebutuhan tanpa memperhatikan seumber daya yang digunakan.

Dengan memiliki strategi promosi yang terstruktur dan dipikirkan dengan baik akan dapat membantu mereka untuk mengidetifikasi segmen konsumen yang berbeda dipasar dan menawarkan solusi kepada mereka. Sehingga mereka akan fokus terhadap strategi-strategi yang sudah dibuat seperti penetapan harga, promosi mingguan dan bulanan, rencana pengembangan produk atau kemasan baru, re-branding produk dan lain sebagainya. Dengan manajemen yang baik maka akan diperoleh laba yang jelas jumlahnya, dan akan terjadi pengambilan keputusan yang tepat. 
Loyalitas Kreativitas Aldi Masyarakat Kreatif
Menciptakan suatu produk yang berbeda, unik dan memiliki nilai estetika yang berbeda dari produk yang sudah beredar dipasar sebelumnya akan menjadikan produk memiliki nilai yang tinggi. Pemasaran atau promosi yang sederhanadengan memanfaatkan media sosial yang ada akan membantu memperkenalkan kepada masyarakat dengan efektif dan efisien.

\section{METODE PELAKSANAAN}

Metode kegiatan yang digunakan kepada anggota UMKM Merta Yasa Gianyar adalah berupa penyuluhan dan simposium, selanjutnya mereka akan diberikan sesi tanya jawab tentang masalah yang dihadapi baik sifatnya pribadi maupun umum. Program Pengabdian Kepada Masyarakat di dibagi menjadi 2 tahap yaitu tahap pertama persiapan yaitu survei lapangan, tahap kedua pelaksanaan yaitu pemberian materi dan pelatihan.

Adapun tahapan dalam pelaksanaan kegiatan Pengabdian Kepada Masyarakat pada kesempatan kali ini dilakukan dalam beberapa tahan yaitu :

\section{Tahap Persiapan}

Adapun tahap-tahap yang kami lakukan dalam Pengabdian Kepada Masyarakat meliputi :

a. Survei awal, pada tahap ini dilakukan survei ke lokasi UMKM Merta Yasa Gianyar

b. Setelah survei maka ditetapkan waktu pelaksanaan dan sasaran peserta kegiatan Penyusunan bahan/materi pelatihan yang meliputi: slide dan makalah untuk kegiatan tentang pemasaran produk kreatif dan inovatif.

2. Tahap Pelaksanaan

Permasalahan yang ada bahwa

UMKM Merta Yasa Gianyar belum mampu mengambil keputusan yang tepat, untuk membantu/menopang perekonomian keluarga dengan cara yang tepat, tanpa meninggalkan kepentingan utama dalam keluarga.

Kegiatan pengabdian ini dikemas dalarn bentuk penyuluhan dan pelatihan. Untuk memberikan solusi terhadap permasalahan di atas maka altematif tindakan meliputi tahapan-tahapan sebagai berikut:

1. Ceramah materi penyuluhann yang terdiridari:

a. Manfaat Pemasaran yang baik

b. Menemukan potensi dari produk kreatif dan Inovatif

c. Membuat rencanakerja membuat produk yang kreatif dan Inovatif

2. Diskusi terkait dengan hambatanmemulai bisnis yang kreatif dan Inovatif.

3. Pelatihan penggunaan media social sebagai media pemasaran efektif.

Untuk kegiatan-kegiatan yang dilakukan di dalam ruangan, digunakan alat bantu microphone, sebagai pengeras suara. Selain itu untuk lebih memberikan gambaran visualisasi yang menarik dan jelas, maka setiap kegiatan yang dilakukan dalam ruangan juga menggunakan proyektor dan laptop. Setiap kegiatan yang dilaksanakan dalam program ini didokumentasikan dalam bentuk foto dan video.

\section{HASIL DAN PEMBAHASAN}

Pelatihan ini bertujuan agar para anggota khususnya pada UMKM Merta Yasa, Bambu Mas, Desa Belega, Kabupaten Gianyar, Denpasar, Bali yang berjumlah sebanyak 30 orang agar dapat lebih memahami tentang berwirausaha UMKM yang baik dan benar, melakukan pencatatan keuangan sederhana dengan baik sehingga dapat diketahui arus kas masuk dan keluar, memahami tentang manajemen inventory dan pengaturan bahan baku, mengevaluasi tentang promosi, cara pemasaran yang kreatif, inovatif dan efektif dengan biaya yang murah serta memotivasi menumbuhkan jiwa entrepreneur bagi anggota yang belum aktif bergabung sehingga dapat menciptakan peluang usaha yang lebih bernilai ekonomis.

Pelaksanaan Pengabdian Kepada Masyarakat (PKM) dilaksanakan pada tanggal 1-3 Maret 2021. Untuk kegiatan ini di pandu oleh MC yaitu Ibu Juwita Ramadani Fitria, S.S., M.M di dokumentasikan oleh Ibu Selvy Dwi Widiyanti, S.E., M.M. dan pemaparan dilakukan oleh Ibu Lismiatun, S.E., M.M., Ibu Hira Maulida, S.E. M.M. dan Bapak Bambang 
Loyalitas Kreativitas Aldi Masyarakat Kreatif

\section{Purnomo Yanuarso, ST, M.Si}

Beberapa faktor yang mendukung terlaksananya kegiatan Pengabdian Kepada Masyarakat ini adalah besarnya minat dan antusiasme peserta selama kegiatan dengan memberikan saran dan input untuk terus diadakannya kegiatan Pengabdian Kepada Masyarakat yang berkelanjutan di wilayah mereka serta dukungan dari para masyarakat setempat dalam memberikan informasi dan kontribusinya sehingga kegiatan pelatihan yang di adakan di UMKM Merta Yasa, Desa Belega, Kabupaten Gianyar, Denpasar, Bali dapat berlangsung dengan lancar dan efektif.

Sedangkan yang menjadi faktor penghambat dalam pelaksanaan kegiatan Pengabdian Kepada Masyarakat kali ini adalah karena ditengah pandemi Covid-19, oleh karena itu pelaksanaan kegiatan di lakukan secara terbatas baik jumlah peserta ataupun waktu kegiatannya. Semua harus mematuhi tetap menerapkan protokol kesehatan yang ketat bagi seluruh peserta demi keamanan bersama.

Permasalahan lain yang timbul yaitu tidak adanya media pembelajaran yang memadai untuk menjelaskan suatu konsep di luar praktikum. Hal ini akan mempersulit masyarakat dalam memahami konsep sehingga tak jarang masyarakat memahami diluar konsep yang sebetulnya, jadi dosen harus kreatif dan inovatif lagi dalam menyampaikan materi.

\section{KESIMPULAN DAN SARAN}

\section{Kesimpulan}

\section{Kegiatan Pengabdian Kepada} Masyarakat (PKM) dengan judul Penyuluhan Pemahaman Pemasaran Produk Yang Kreatif dan Inovatif Pada UMKM MERTA YASA, Bambu Mas, Desa Belega, Kabupaten Gianyar secara umum berjalan dengan lancar dan tertib dapat ditarik beberapa kesimpulan yaitu :

1. Masyarakat antusias dalam menyimak penjelasan materi teori dan peragaan yang diberikan. Antusiasme masyarakatpun berlanjut saat sesi tanya jawab seputar bisnis yang kreatif dan Inovatif. Kegiatan PKM ini dinilai berjalan efektif karena tingkat ketertarikan masyarakat cukup tinggi terhadap pembelajaran pemasaran dan bisnis online rumahan.

2. Pelatihan pembukuan keuangan sederhana, manajemen inventory, promosi dan pemasaran yang efektif dan inovatif pada anggota dan pemilik UMKM Merta Yasa, Gianyar, Bali sangat menguggah semangat mereka sebagai generasi muda dan entrepreneur muda yang baru memulai bisnis untuk lebih tertib dan disiplin dalam manajemen usaha mereka.

3. Penggunaan HP dan teknologi terbaru dapat digunakan lebih efektif untuk membantu efisiensi kinerja mereka. Karena perkembangan industri ekonomi kreatif tidak terlepas dari e-commerce, tidak hanya dari segi peralatan namun juga dari segi pemasaran seperti contohnya membawa UKM ke dunia digital yang sedang marak di masyarakat saat ini sehingga usaha lebih dikenal oleh masyarakat. UKM di Indonesia mulai banyak merambah ke dunia digital seperti e-commerce dan marketplace. Ini adalah wadah bagi pemilik UKM untuk memaksimalkan usaha dan potensi kreatifitasnya. Optimasi penggunaan $e$ commerce dan media sosial dapat dilakukan agar UMKM mereka dapat berkembang lebih pesat lagi.

\section{Saran}

Mengingat besarnya manfaat kegiatan Pengabdian Kepada Masyarakat ini, maka selanjutnya perlu di lakukan beberapa hal antara lain :

1. Mengadakan sosialisasi dan pelatihan serupa pada anggota dan pemilik UMKM atau organisasi pemuda lainnya seperti komunitas-komunitas UMKM lainnya di tingkat Kelurahan ataupun Kecamatan wilayah yang lain, dengan materi yang serupa.

2. Adanya kesinambungan program pasca kegiatan Pengabdian Kepada Masyarakat ini sehingga para peserta benar-benar dapat mempraktekkan atau mengaplikasikan materi, pengalaman dan pengetahuan yang sudah di berikan sehingga dapat langsung di rasakan hasilnya dan dilakukan perbaikan jika terjadi kendala saat pelaksanaan.

3. Adanya komitmen dari semua pihak 
membantu dalam memberikan strategi promosi pemasaran produk yang dihasilkan dengan cara yang efektif dan efisien serta lebih tepat sasaran sehingga dapat membantu mempercepat perputaran keuangan dan stock mereka.

\section{DAFTAR PUSTAKA}

Adinugraha, $\quad$ Fajar.(2017). $\quad$ Media PembelajaranBiologiBerbasisEcopreneurs hip

Assauri, Sofjan. (2013), Manajemen Pemasaran Dasar, Konsep, Dan Positioning, Jakarta:PT. Radja Grafindo Persada

Buchari Alma. (2013), Manjemen Pemasaran Dan Pemasaran Jasa, Bandung:Alfabeta.

Iskandar, Putong. (2010), Economics Pengantar Mikro \& Makro, Jakarta:Mitra Wacana Media

Kotler, Philip dan Gary Amstrong, (2014). Dasar-dasar Pemasaran. Edisi Kesembilan Jilid Satu. Jakarta:PT. Indeks Kelompok Gramedia.

Kotler, Philip, (2013), Manjemen Pemasaran, Edisi kedelapan, Jakarta:Salemba Empat

Samuelson, P.A, Putong. (2013), Peluang Usaha, Jakarta:PT. Erlangga

Suryana, Kewirausahaan Full Edision (2013), Jakarta:Salemba Empat.

\section{Sumber Dari Internet:}

https://www.dosenpendidikan.co.id/peluangusaha dilihat pada tanggal 15 Februari 2021 pukul 14.15 WIB.

https://www.academia.edu/7878221/_EKO_3 046_Pengertian_Ekonomi_Menurut_Para Ahli dilihat pada tanggal 15 Februari 2021 pukul 15.30 WIB.

https://www.zonareferensi.com/pengertian-

kewirausahaan/dilihat pada tanggal 23 Februari 2021 pukul 10.10 WIB http://www.sarjanaku.com/2012/12/pengertian -produksi-luas-menurut-

para.html?m=1dilihat pada tanggal 4 Maret 2021 pukul 10.45 WIB

https://ilmumanajemenindustri.com/pengertia n-manajemen-persediaan-inventorymanagement-2/ dilihat pada tanggal 4 Maret 2021 pukul 11.15 WIB

\section{Jurnal}

Pasaribu, V. L. D., Agrasadya, A., Shabrina, N., \& Krisnaldy, K. (2020). Menjadi Enterpreneur Muda Yang Memiliki Jiwa Leadership Untuk Menghadapi Masa Depan. Abdi Laksana: Jurnal Pengabdian Kepada Masyarakat, 1(1).

Pasaribu, V. L. D., Susanti, F., \& Hartuti, E. T. K. (2019). Memotivasi Siswa dan Siswi SMK Letris Indonesia di Dalam Menentukan Pilihan Untuk Melanjutkan Pendidikan Atau Bekerja Setelah Lulus Sekolah. Jurnal Pengabdian Dharma Laksana, 1(2), 161-172.

Pasaribu, V. L. D., Sulaiman, S., Sutiman, S., Thaharudin, T., \& Purnomo, B. Y. (2020). Pengenalan Letak Posyandu Terdekat Dikelurahan Pisangan Dengan Manajemen Pemasaran Revolusi 4.0 Untuk Meningkatkan Pengetahuan Masyarakat Letak Dan Fungsi Posyandu Terdekat Pada Kelurahan Pisangan. Dedikasi Pkm, 1(1), 105-110.

Pasaribu, V. L. D., Oktrima, B., Prabowo, B., Arianto, N., \& Haryoko, U. B. (2020). Progam Pendampingan Dan Penyelenggaraan Pendidikan Anak Pada Usia Dini Terhadap Prestasi Belajar Dilingkungan Rt 020 Rw 009. Kel Giri Peni. Kec Wates. Yogyakarta. Jurnal Lokabmas Kreatif, 1(1), 71-75.

Pasaribu, V. L. D., Jannah, M., Fazar, M., Putra, S. P., Monalisa, M., \& Sofa, M. (2021). MENINGKATKAN PRODUKTIVITAS USAHA DIMASA PANDEMI PADA IBU PKK RT 004/003 
Loyalitas Kreativitas Aldi Masyarakat Kreatif
Program Studi Ekonomi Manajemen Universitas Pamulang Jurnal LOKABMAS Kreatif Vol.02,No.02.Juli 2021 Hal.51-57 Email:jurnalkreatif.manajemen@gmail.com \begin{tabular}{lrr} 
KELURAHAN & SAWAH & BARU \\
CIPUTAT, & \multicolumn{2}{c}{ TANGERANG } \\
SELATAN. Abdi & Laksana: & Jurnal \\
Pengabdian & Kepada & Masyarakat, 2(2),
\end{tabular} 295-301.

Pasaribu, V. L. D., Yuniati, H. L., Pranata, R., Sembayu, R., Purba, S. M., \& Nurbayani, T. T. A. (2021). MANAJEMEN KEUANGAN UNTUK MENGHADAPI DAN BERTAHAN DI ERA COVID 19. Jurnal Abdimas Tri Dharma Manajemen, 2(2), 12-18.

Pasaribu, V. L. D., Dwiyatni, A., Sabina, C., Ridwan, M., Gunawan, D. D., \& Noviani, B. C. (2021). EVALUASI PENERAPAN 3M DIMASA PANDEMIC COVID 19. Jurnal Abdimas Tri Dharma Manajemen, 2(2), 54-60.

Pasaribu, V. L. D., Syafei, A. N., Farhan, A., Aufaizah, A., Irani, C., \& Firtiayani, S. R. (2021). PENGARUH DISPLIN PROTOKOL KESEHATAN TERHADAP PENCEGAHAN PENULARAN VIRUS COVID19. Jurnal Abdimas Tri Dharma Manajemen, 2(2), 91-98.

Priadi, A., Pasaribu, V. L. D., Virby, S., Sairin, S., \& Wardani, W. G. (2020). Penguatan Ekonomi Kreatif Berbasis Sumber Daya Desa Dikelurahan Rempoa. Abdi Laksana: Jurnal Pengabdian Kepada Masyarakat, 1(3), 356-35

Sashi, C.M. (2012). "Customer engagement, buyer-seller relationships, and social media". Management Decision, Vol. 50 Iss: 2, pp.253-272.

Vivek, S. D., Beatty, S. E., \& Morgan, R. M. (2012). Customer Engagement: Exploring Customer Relationships beyond
Purchase. Journal of Marketing Theory and Practice, vol. 20, no. 2, pp. 127-145.

\section{Skripsi}

Cristiani D. Manengal (2015) Pengaruh Kualitas Layanan, Kualitas Produk Dan Penetapan Harga Terhadap Keputusan Pembelian Pada Cv. Esa Genangku (Esacom) Manado (X1) Kualitas Layanan (X2) Kualitas Produk (X3) Penetapan Harga (Y) Keputusan Pembelian Analisis Regresi Linier Berganda Kualitas Layanan, Kualitas Produk, dan Penetapan Harga secara bersama-sama berpengaruh positif dan signifikan terhadap terhadap Keputusan pembelian.

\section{DOKUMENTASI FOTO KEGIATAN}
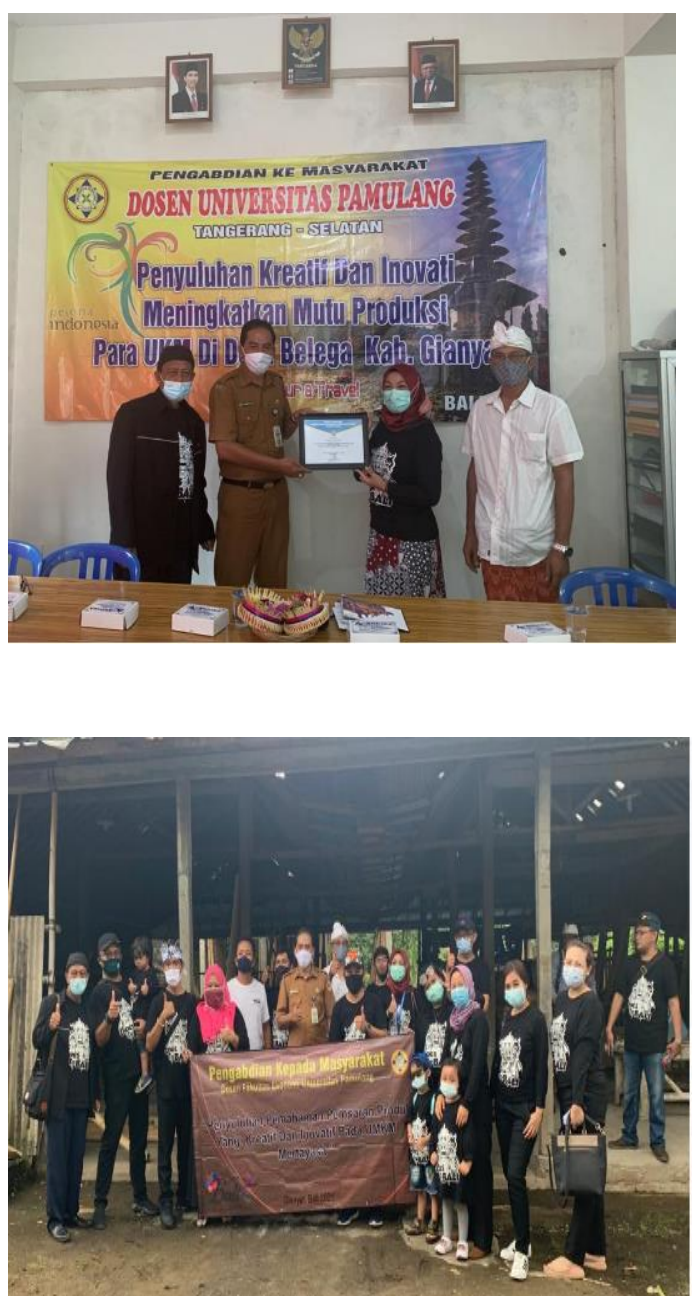